\title{
Complex Deoxidation Equilibria of Molten Iron by Aluminum and Calcium
}

\author{
Kenji TAGUCHI, Hideki ONO-NAKAZATO, ${ }^{1)}$ Tateo USUI, ${ }^{1)}$ Katsukiyo MARUKAWA, ${ }^{2)}$ Ken KATOGI ${ }^{3)}$ \\ and Hiroaki KOSAKA ${ }^{4)}$
}

Graduate Student and JSPS Research Fellow, Graduate School of Engineering, Osaka University, 2-1 Yamadaoka, Suita, Osaka 565-0871 Japan. $\quad$ 1) Course of Materials Science and Engineering, Division of Materials Science and Manufacturing, Graduate School of Engineering, Osaka University, 2-1 Yamadaoka, Suita, Osaka 565-0871 Japan.

2) Center for Advanced Science and Innovation, Osaka University, 2-1 Yamadaoka, Suita, Osaka 565-0871 Japan.

3) Heraeus Electro-Nite Japan, LTD., 1-7-40 Mishimae, Takatsuki, Osaka 569-0835 Japan.

4) TOYO Engineering and Research Center Co., Ltd., 2-2-1 Kasuga, Ibaraki, Osaka 567-0031 Japan.

(Received on June 17, 2005; accepted on July 20, 2005)

\begin{abstract}
The influence of oxygen potential in molten steel on the steelmaking reactions, such as desulfurization and denitrogenization by fluxes, is very significant, and it is important to control oxygen content of the molten steel. The use of the strong deoxidizing agents, such as Al and $\mathrm{Ca}$, is effective for decreasing oxygen content of steel, and several researches on the complex deoxidation have been carried out. However, the experimental data do not necessarily accord with the thermodynamically calculated ones, because the reliable thermodynamic data on $\mathrm{Ca}$ deoxidation of molten iron are unavailable. In the present study, the complex deoxidation equilibria of molten iron by $\mathrm{Al}$ and $\mathrm{Ca}$ have been examined at $1873 \mathrm{~K}$. The oxygen activity in molten iron deoxidized by $\mathrm{Al}$ and $\mathrm{Ca}$ has been measured by an electro motive force (EMF) method at $1873 \mathrm{~K}$. The $\mathrm{Al}-\mathrm{Ca}$ complex deoxidation equilibria are presented, and the validity is confirmed from the present experimental results and the previous ones in the literature on the complex deoxidation by $\mathrm{Al}$ and $\mathrm{Ca}$. The Al-Ca deoxidation equilibria presented in the present study can represent the relationship of Fe-Al$\underline{\text { Ca-O }}$ system more properly than the previously reported ones.

KEY WORDS: complex deoxidation; aluminum; calcium; oxygen activity; EMF method; steelmaking; CaO; $\mathrm{Al}_{2} \mathrm{O}_{3}$.
\end{abstract}

\section{Introduction}

In recent years, with an increase of demands for ultra clean steel, the more exact control of the contents of impurity elements in steel has been required. It has become necessary to decrease and to control the contents of the impurities in steel under a few mass ppm. In particular, the influence of oxygen potential in molten steel on the steelmaking reactions, such as desulfurization and denitrogenization by fluxes, is very significant; it is important to control oxygen content of the molten steel. The use of the strong deoxidizing agents, such as $\mathrm{Al}$ and $\mathrm{Ca}$, is effective for decreasing oxygen content of steel. The complex deoxidation by Al and $\mathrm{Ca}$ is considered to be more effective, and several investigations on the complex deoxidation have been carried out. $^{1,2)}$ However, the experimental data are not necessarily in accord with the thermodynamically calculated ones, because the thermodynamic data on $\mathrm{Ca}$ deoxidation equilibrium of molten iron are considered not to be reliable enough, which may be caused by the difficulty of the measurements. For this reason, it is necessary to re-examine the complex deoxidation equilibria of molten iron by $\mathrm{Al}$ and $\mathrm{Ca}$, around a few to 10 mass ppm oxygen, in particular. Recently, the single deoxidation equilibrium by $\mathrm{Al}$ or $\mathrm{Ca}$ was investigated by Itoh et al. ${ }^{3,4)}$ In the present study, the complex deoxidation equilibria of molten iron by $\mathrm{Al}$ and $\mathrm{Ca}$ are calculated at $1873 \mathrm{~K}$, using the thermodynamic data by Itoh et al. The oxygen activity in molten iron deoxidized by $\mathrm{Al}$ and $\mathrm{Ca}$ is measured by an electro motive force (EMF) method, and the validity of the Al-Ca complex deoxidation equilibria derived in the present study is discussed from the present and previous experimental results ${ }^{1,2)}$ on the complex deoxidation by $\mathrm{Al}$ and $\mathrm{Ca}$.

\section{Deoxidation Equilibria of Molten Iron by $\mathrm{Al}$ and $\mathrm{Ca}$}

The deoxidation reactions of molten iron by $\mathrm{Al}$ and $\mathrm{Ca}$ are represented by

$$
\begin{aligned}
& \mathrm{Al}_{2} \mathrm{O}_{3}(\mathrm{~s})=2 \underline{\mathrm{Al}}(\operatorname{mass} \%, \text { in } \mathrm{Fe})+3 \underline{\mathrm{O}}(\operatorname{mass} \%, \text { in } \mathrm{Fe}) \ldots . \\
& \mathrm{CaO}(\mathrm{s})=\underline{\mathrm{Ca}}(\operatorname{mass} \%, \text { in } \mathrm{Fe})+\underline{\mathrm{O}}(\operatorname{mass} \%, \text { in } \mathrm{Fe}) \ldots \ldots \ldots
\end{aligned}
$$

The equilibrium constants for Eqs. (1) and (2), $K_{(1)}$ and $K_{(2)}$, are given respectively as follows ${ }^{3,4)}$ :

$$
\log K_{(1)}=\log \left(\frac{a_{\mathrm{Al}}^{2} \cdot a_{\mathrm{O}}^{3}}{a_{\mathrm{Al}_{2} \mathrm{O}_{3}}}\right)=11.62-45300 / T
$$




$$
\log K_{(2)}=\log \left(\frac{a_{\mathrm{Ca}} \cdot a_{\mathrm{O}}}{a_{\mathrm{CaO}}}\right)=-3.29-7220 / T . .
$$

where $a_{\mathrm{Al}}, a_{\mathrm{Ca}}$ and $a_{\mathrm{O}}$ denote the activities of $\mathrm{Al}, \mathrm{Ca}$ and $\mathrm{O}$ in molten iron relative to the dilute solution, $a_{\mathrm{Al}_{2} \mathrm{O}_{3}}$ and $a_{\mathrm{CaO}}$ the activities of $\mathrm{Al}_{2} \mathrm{O}_{3}$ and $\mathrm{CaO}$ relative to the pure solid, respectively, and $T$ the absolute temperature $(\mathrm{K})$. The activities of $\mathrm{Al}, \mathrm{Ca}$, and $\mathrm{O}$ in molten iron are defined as follows:

$$
\begin{aligned}
& a_{\mathrm{Al}}=f_{\mathrm{Al}}[\operatorname{mass} \% \mathrm{Al}] \\
& a_{\mathrm{Ca}}=f_{\mathrm{Ca}}[\operatorname{mass} \% \mathrm{Ca}] \\
& a_{\mathrm{O}}=f_{\mathrm{O}}[\operatorname{mass} \% \mathrm{O}] .
\end{aligned}
$$

The activity coefficient of element $i$ relative to the dilute solution, $f_{i}$, is given by ${ }^{5}$

$$
\begin{aligned}
\log f_{i}= & \sum_{j} e_{i}^{j}[\operatorname{mass} \% j] \\
& +\sum_{j} \sum_{k} r_{i}^{(j, k)}[\operatorname{mass} \% j][\operatorname{mass} \% k] \quad(j \leq k) \ldots
\end{aligned}
$$

where $e_{i}^{j}$ denotes the first-order mass percent interaction parameter of $j$ for $i$, and $r_{i}^{(j, k)}$ the second-order mass percent interaction parameter between $j$ and $k$ for $i$. The values for the interaction parameters used in the present study are shown in Table 1. The interaction parameters between the two of $\mathrm{Al}, \mathrm{Ca}$ and $\mathrm{O}$ are different from each other in the literatures. ${ }^{3,4,6-8)}$ In the present study, the values reported by Itoh et al. are used, because they can reasonably explain the experimental results of the single deoxidation of $\mathrm{Al}$ or $\mathrm{Ca}$ over a wider concentration range, and are considered to be one of the most reliable data at present. The complex deoxidation equilibria by $\mathrm{Al}$ and $\mathrm{Ca}$ are calculated at $1873 \mathrm{~K}$ by solving Eqs. (1) and (2) simultaneously, using Eqs. (3) through (8) and the activities of $\mathrm{Al}_{2} \mathrm{O}_{3}$ and $\mathrm{CaO}$ in $\mathrm{CaO}$ $\mathrm{Al}_{2} \mathrm{O}_{3}$ system. ${ }^{9,10)}$ In the case of the equilibrium with calcium aluminates $\left(\mathrm{CaO} \cdot \mathrm{Al}_{2} \mathrm{O}_{3}(\mathrm{CA}), \mathrm{CaO} \cdot 2 \mathrm{Al}_{2} \mathrm{O}_{3}\left(\mathrm{CA}_{2}\right)\right.$, or $\left.\mathrm{CaO} \cdot 6 \mathrm{Al}_{2} \mathrm{O}_{3}\left(\mathrm{CA}_{6}\right)\right)$, the activities of $\mathrm{Al}_{2} \mathrm{O}_{3}$ and $\mathrm{CaO}$ are estimated from the standard Gibbs energies of formation of those oxides reported by Hallstead, ${ }^{11)}$ which are shown in Table 2. The relationship among the contents of $\mathrm{Al}, \mathrm{Ca}$, and $\mathrm{O}$ is investigated as follows:

1. The activities of $\mathrm{CaO}$ and $\mathrm{Al}_{2} \mathrm{O}_{3}$ are determined by setting a composition of $\mathrm{CaO}-\mathrm{Al}_{2} \mathrm{O}_{3}$ system.

2. By assuming an arbitrary oxygen content of molten iron, the relationship between $\mathrm{Al}$ and $\mathrm{Ca}$ contents which satisfies the equilibrium of Eq. (1) is calculated from Eqs. (3), (5), (7) and (8).

3. Similarly, the relationship between $\mathrm{Al}$ and $\mathrm{Ca}$ contents which satisfies the equilibrium of Eq. (2) is calculated by using Eqs. (4), (6), (7) and (8).

4. The composition of molten iron in equilibrium with the setting composition of $\mathrm{CaO}-\mathrm{Al}_{2} \mathrm{O}_{3}$ system can be determined from the intersection of the relationships between $\mathrm{Al}$ and $\mathrm{Ca}$ contents in Steps 2 and 3.

5. The calculations in Steps 2 to 4 are repeated at oxygen contents ranging from $10^{-5}$ to $10^{-2}$ mass $\%$.

By repeating the above calculations over all compositions of $\mathrm{CaO}-\mathrm{Al}_{2} \mathrm{O}_{3}$ system, the phase diagram for the complex deoxidation equilibria by $\mathrm{Al}$ and $\mathrm{Ca}$ at $1873 \mathrm{~K}$ is derived
Table 1. The interaction parameters for $\mathrm{Fe}-\mathrm{Al}-\mathrm{Ca}-\mathrm{O}$ system at $1873 \mathrm{~K}$ used in the present study.

\begin{tabular}{c|c|c|c|c|c}
\hline$i$ & $j$ & $e_{i}^{j}$ & $r_{i}^{j}$ & $r_{i}^{(i, j)}$ & Ref. \\
\hline \hline \multirow{4}{*}{$\mathrm{Al}$} & $\mathrm{Al}$ & 0.0430 & - & - & $6)$ \\
& $\mathrm{Ca}$ & -0.047 & - & - & $6)$ \\
& $\mathrm{O}$ & -1.98 & 40 & -0.0284 & $4)$ \\
\hline \multirow{3}{*}{$\mathrm{Ca}$} & $\mathrm{Al}$ & -0.072 & - & - & $6)$ \\
& $\mathrm{Ca}$ & -0.002 & - & - & $6)$ \\
& $\mathrm{O}$ & -780 & 650000 & -90000 & $3)$ \\
\hline \multirow{3}{*}{$\mathrm{O}$} & $\mathrm{Al}$ & -1.17 & -0.01 & 47.4 & $4)$ \\
& $\mathrm{Ca}$ & -313 & -18000 & 520000 & $3)$ \\
& $\mathrm{O}$ & -0.174 & - & - & $6)$ \\
\hline
\end{tabular}

Table 2. Activities of $\mathrm{Al}_{2} \mathrm{O}_{3}$ and $\mathrm{CaO}$ in the coexistence of two solid phases.

\begin{tabular}{cc|c|c}
\hline & Equilibrium phase & $a_{\mathrm{Al} \mathrm{O}_{3}}$ & $a_{\mathrm{CaO}}$ \\
\hline \hline (a) & $\mathrm{Al}_{2} \mathrm{O}_{3}(\mathrm{~s})+\mathrm{CaO} \cdot 6 \mathrm{Al}_{2} \mathrm{O}_{3}$ & 1 & $3.28 \times 10^{-3}$ \\
(b) $\mathrm{CaO} \cdot 6 \mathrm{Al}_{2} \mathrm{O}_{3}+\mathrm{CaO} \cdot 2 \mathrm{Al}_{2} \mathrm{O}_{3}$ & 0.811 & 0.0115 \\
(c) $\mathrm{CaO} \cdot 2 \mathrm{Al}_{2} \mathrm{O}_{3}+\mathrm{CaO} \cdot \mathrm{Al}_{2} \mathrm{O}_{3}$ & 0.30 & 0.084 \\
\hline
\end{tabular}

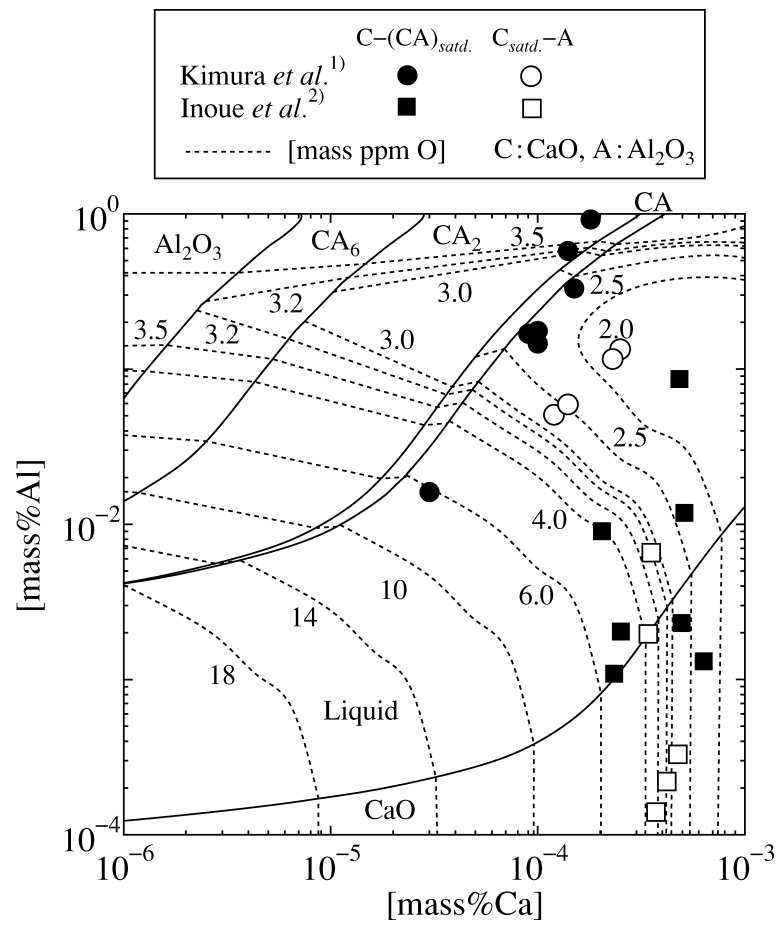

Fig. 1. Complex deoxidation equilibria of molten iron by $\mathrm{Al}$ and $\mathrm{Ca}$ at $1873 \mathrm{~K}$.

and is described in Fig. 1. The dependencies of oxygen content and oxygen activity on aluminum content for the complex deoxidation by $\mathrm{Al}$ and $\mathrm{Ca}$ saturated with $\mathrm{CaO}$. $\mathrm{Al}_{2} \mathrm{O}_{3}$ or $\mathrm{CaO}$ are respectively compared with those for the single deoxidation by $\mathrm{Al}$ in Figs. 2(a) and 2(b). It is found from Fig. 2(a) that the Al content at the lowering limit of oxygen content is lower under the condition of Al-Ca complex deoxidation saturated with $\mathrm{CaO}$ in comparison with that saturated with $\mathrm{CaO} \cdot \mathrm{Al}_{2} \mathrm{O}_{3}$.

\section{Experimental}

The high purity electrolytic iron was put in an alumina 

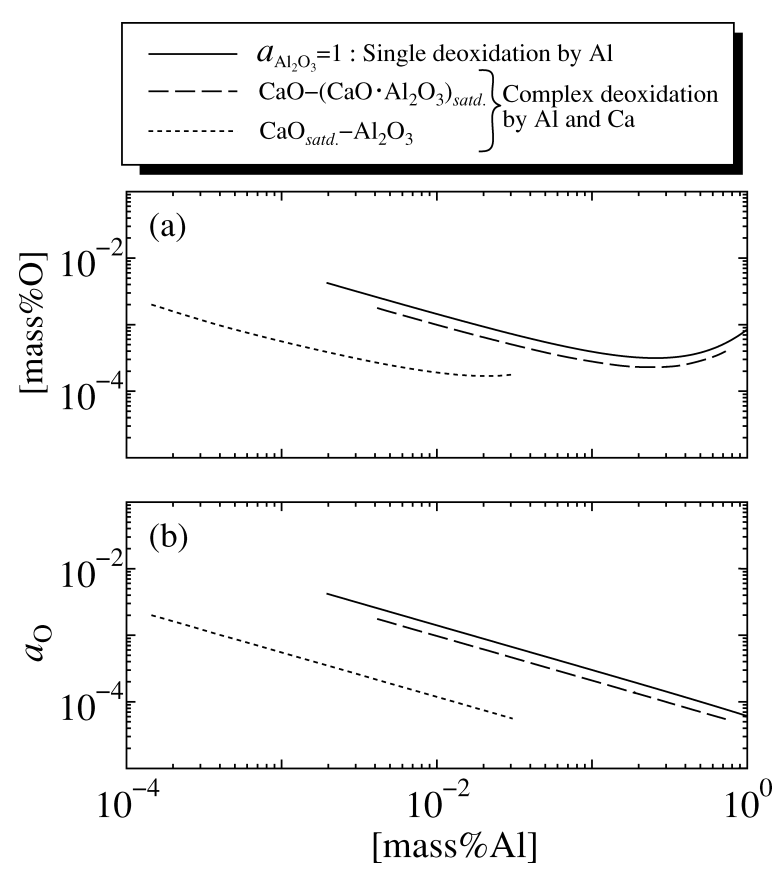

Fig. 2. Effect of oxygen content and activity on aluminum content under several deoxidation conditions at $1873 \mathrm{~K}$.

crucible (38-mm o.d., 45-mm height, $30-\mathrm{cm}^{3}$ volume) and was inductively heated in $\mathrm{Ar}-\mathrm{H}_{2}$ mixture. After the temperature reached $1873 \mathrm{~K}$, hydrogen gas was blown onto the metal surface at a flow rate of $250 \mathrm{~cm}^{3} / \mathrm{min}$ (s.t.p.) for $1 \mathrm{~h}$. After deoxidation, aluminum was added, and the sample was held for $5 \mathrm{~min}$. Then, the sample was quickly cooled, and $\mathrm{Fe}-\mathrm{Al}$ alloy $([$ mass ppm $\mathrm{O}]=10-15)$ was prepared. The preparation of $\mathrm{CaO}-\left(\mathrm{CaO} \cdot \mathrm{Al}_{2} \mathrm{O}_{3}\right)_{\text {satd. }}$ slag and the experiments were conducted by using the electric resistance furnace consisted of $\mathrm{MoSi}_{2}$ heating elements. The slag of $\mathrm{CaO}-\left(\mathrm{CaO} \cdot \mathrm{Al}_{2} \mathrm{O}_{3}\right)_{\text {satd }}$ was made by mixing reagent grades of $\mathrm{CaO}$ and $\mathrm{Al}_{2} \mathrm{O}_{3}$ at the molar ratio of 1 to 1 in a carbon crucible at $1873 \mathrm{~K}$ in an argon atmosphere. The prepared $\mathrm{Fe}-\mathrm{Al}$ alloy weighing $60 \mathrm{~g}$ and $\mathrm{CaO}-\left(\mathrm{Al}_{2} \mathrm{O}_{3} \cdot \mathrm{CaO}\right)_{\text {satd. }}$ slag weighing 5-6 $\mathrm{g}$ were placed in an alumina crucible $(25-\mathrm{mm}$ o.d., 20-mm i.d., 120-mm length), and was held for $1.5 \mathrm{~h}$ at $1873 \mathrm{~K}$ in an argon atmosphere. Then, the oxygen activity in molten alloy was measured by an electro motive force (EMF) method by using the oxygen sensor shown in Fig. 3. The constitution of the oxygen sensor is as follows:

$$
\text { (I) } \mathrm{Mo}, \mathrm{Nb} / \mathrm{NbO} \mid \mathrm{O}^{2-} \text { (MSZ) } \mid \text { (II) } \mathrm{Mo}, \underline{\mathrm{O}} \text { (in Fe) . }
$$

The solid electrolyte of the oxygen sensor is a magnesia stabilized zirconia $\left(\mathrm{ZrO}_{2}-8 \mathrm{~mol} \% \mathrm{MgO}(\mathrm{MSZ})\right)$, and the reference substances are the regent grades of $\mathrm{Nb}$ and $\mathrm{NbO}$ at a molar ratio of 9 to 1 . The molybdenum rod (3-mm o.d.) and wire (1-mm o.d.) are used as contact leads to the melt and the reference substances, respectively. After the experiment, aluminum and calcium contents of the metal samples were analyzed by an inductively coupled plasma (ICP) emission spectrometry.

\section{Results and Discussion}

\subsection{Measurement of Oxygen Activity in Molten Iron}

The experimental results are summarized in Table 3. The variation of the electro motive force, $E(\mathrm{~V})$, with time is ex-

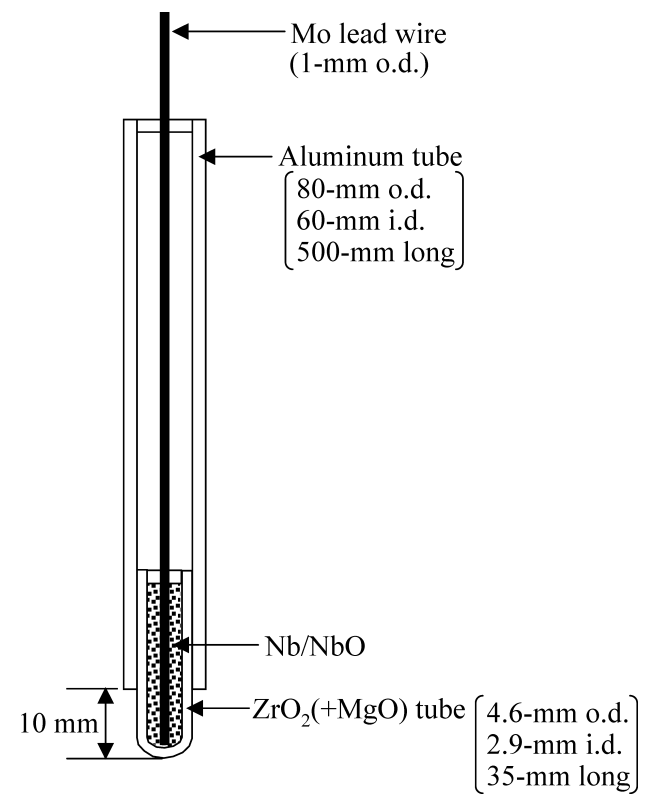

Fig. 3. Schematic cross section of oxygen sensor used in the present study.

Table 3. The aluminum and calcium contents of molten iron, electro motive force and oxygen activity.

\begin{tabular}{c|c|c|c|c}
\hline No. & {$[$ mass\%Al] } & [mass ppm Ca] & $E(\mathrm{mV})$ & $a_{\mathrm{O}} \times 10^{4}$ \\
\hline \hline 1 & 0.032 & $<3$ & 15.5 & 3.2 \\
2 & 0.050 & $<3$ & -7.0 & 2.1 \\
3 & 0.050 & $<3$ & 3.0 & 2.6 \\
4 & 0.098 & $<3$ & -10.1 & 2.0 \\
5 & 0.300 & $<3$ & -13.9 & 1.9 \\
6 & 0.570 & $<3$ & -45.0 & 0.99 \\
7 & 0.570 & $<3$ & -55.0 & 0.79 \\
8 & 0.865 & $<3$ & -38.8 & 1.1 \\
\hline
\end{tabular}

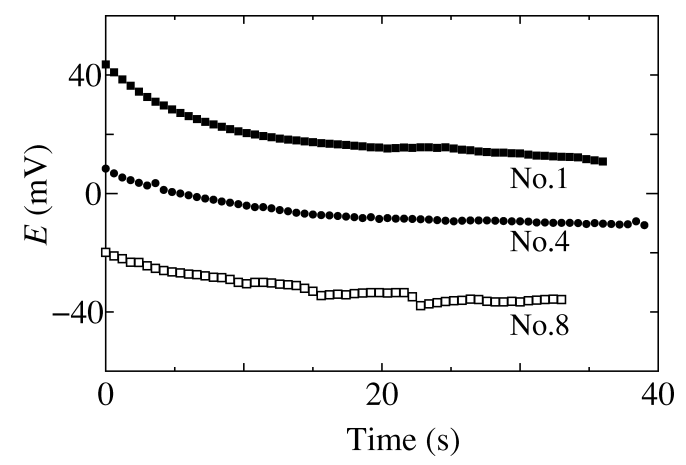

Fig. 4. Variation of electro motive force with time for Run Nos. 1,4 and 8 .

emplified in Fig. 4. The $E$ values become almost constant after about $20 \mathrm{~s}$, and oxygen activity in molten alloy, $a_{\mathrm{O}}$, is determined by the following equations:

$$
\begin{array}{r}
a_{\mathrm{O}}=K_{(11)}\left(\left(P_{\mathrm{e}}^{\prime 1 / 4}+P_{\mathrm{O}_{2}(\mathrm{I})}^{1 / 4}\right) \exp \left(\frac{E F}{R T}\right)-P_{\mathrm{e}}^{\prime 1 / 4}\right) \ldots \\
\frac{1}{2} \mathrm{O}_{2}(\mathrm{~g})=\underline{\mathrm{O}}(\operatorname{mass} \%, \text { in } \mathrm{Fe}) \ldots \ldots \ldots \ldots \ldots . . . . . . . .1
\end{array}
$$




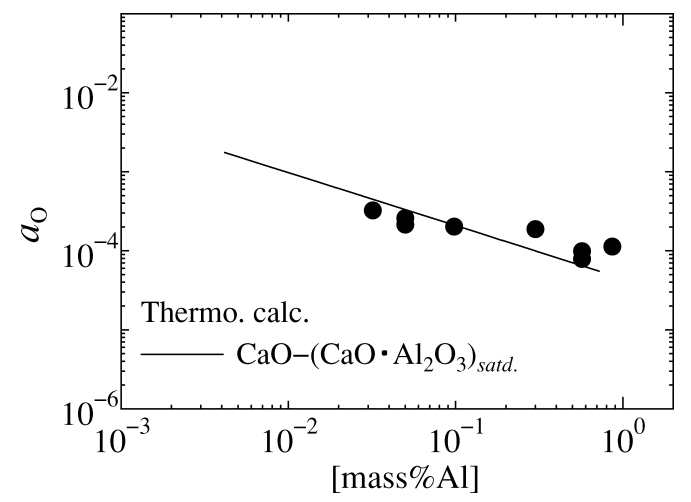

Fig. 5. Effect of aluminum content on oxygen activity in molten iron at $1873 \mathrm{~K}$.

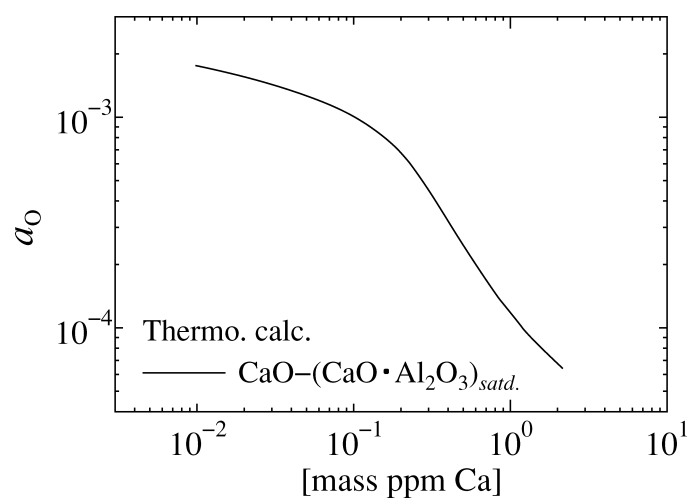

Fig. 6. Effect of calcium content on oxygen activity in molten iron at $1873 \mathrm{~K}$.

$$
\begin{gathered}
K_{(11)}=\exp \left(\left(\frac{117000}{T}+2.89\right) / R\right) \\
P_{\mathrm{e}}^{\prime}=\exp \left(56.17-\frac{171051}{T}\right) \ldots \ldots . . .
\end{gathered}
$$

where $F$ denotes Faraday constant $(=96.5 \mathrm{kC} / \mathrm{mol}), K_{(11)}$ the equilibrium constant of Eq. $(11),{ }^{8)} P_{\mathrm{e}}^{\prime}$ the electronic conductivity parameter (atm), ${ }^{12)} P_{\mathrm{O}_{(\mathrm{I}}}$ the equilibrated oxygen partial pressure at the reference electrode $(\mathrm{atm}),{ }^{13)}$ and $R$ the gas constant $(=8.314 \mathrm{~J} /(\mathrm{mol} \cdot \mathrm{K}))$. Oxygen activities in the molten iron, which are obtained from the experimental results equilibrated with $\mathrm{CaO}-\left(\mathrm{Al}_{2} \mathrm{O}_{3} \cdot \mathrm{CaO}\right)_{\text {satd. }}$ slag, are plotted as a function of aluminum content in Fig. 5. The calculated curve is also shown in Fig. 5 under the same deoxidation condition. The experimental values of oxygen activity are in good accord with the calculated curves, which suggests that the Al-Ca complex deoxidation equilibria derived in the present study are valid. Moreover, the calculated oxygen activity is drawn as a function of calcium content in Fig. 6. As shown in Table 3, the calcium contents of the metal samples are below 3 mass ppm in all experiments, and it was impossible to analyze the calcium content exactly. The range of the oxygen activity measured in the present study is from $0.79 \times 10^{-4}$ to $3.2 \times 10^{-4}$. It is found from Fig. 6 that the calcium content corresponding to the measured oxygen activities is about 1 mass ppm, which is also in reasonable agreement with the experimental results.
Table 4. The experimental conditions for Al-Ca complex deoxidation investigated by Suito et al.'s group.

\begin{tabular}{c|c|c|c}
\hline & Temperature & Sample & [mass ppm N or S] \\
\hline \hline Kimura et al. ${ }^{1)}$ & & $\mathrm{Fe}-\mathrm{Ca}-\mathrm{Al}-\mathrm{O}-\mathrm{N}$ & $1.5-106$ \\
Inoue et al. ${ }^{2)}$ & $1873 \mathrm{~K}$ & $\mathrm{Fe}-\mathrm{Ca}-\mathrm{Al}-\mathrm{O}-\mathrm{S}$ & $10-483$ \\
\hline
\end{tabular}
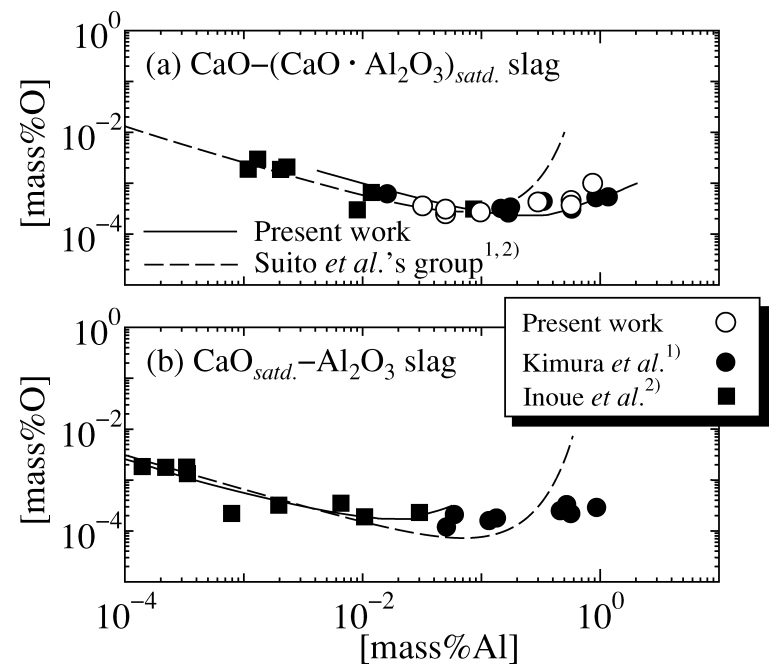

Fig. 7. Relationship between $\mathrm{Al}$ and $\mathrm{O}$ contents of molten iron equilibrated with $\mathrm{CaO}-\left(\mathrm{CaO} \cdot \mathrm{Al}_{2} \mathrm{O}_{3}\right)_{\text {satd. }}$ or $\mathrm{CaO}_{\text {satd. }}{ }^{-}$ $\mathrm{Al}_{2} \mathrm{O}_{3}$ slag at $1873 \mathrm{~K}$.

\subsection{Complex Deoxidation by $\mathrm{Al}$ and $\mathrm{Ca}$}

The experiments on $\mathrm{Ca}-\mathrm{Al}$ deoxidation equilibria of molten iron using $\mathrm{CaO}-\left(\mathrm{CaO} \cdot \mathrm{Al}_{2} \mathrm{O}_{3}\right)_{\text {satd. }}$ and $\mathrm{CaO}_{\text {satd. }}-$ $\mathrm{Al}_{2} \mathrm{O}_{3}$ slags were carried out at $1873 \mathrm{~K}$ by Kimura et al. ${ }^{1)}$ and by Inoue et al. $^{2)}$ The experimental conditions are tabulated in Table 4, and the results are plotted in Fig. 1. It is found that the relationship of $\mathrm{Al}$ and $\mathrm{Ca}$ contents equilibrated with $\mathrm{CaO}-\left(\mathrm{CaO} \cdot \mathrm{Al}_{2} \mathrm{O}_{3}\right)_{\text {satd. }}$ slag investigated by Kimura et al. reasonably agrees with the relationship derived in the present study; Ca content increases with increasing Al content along the solid curve saturated with CA. Most of other experimental data are found in the liquid phase region. In Inoue et al.'s experiments, molten iron contains 10 to 483 mass ppm sulfur, which may explain the disagreement with the present calculation. The relationships between $\mathrm{Al}$ and $\mathrm{O}$ contents of molten iron are shown in Figs. 7(a) and 7(b) from the results equilibrated respectively with $\mathrm{CaO}-$ $\left(\mathrm{CaO} \cdot \mathrm{Al}_{2} \mathrm{O}_{3}\right)_{\text {satd. }}$ and $\mathrm{CaO}_{\text {satd. }}-\mathrm{Al}_{2} \mathrm{O}_{3}$ slags by Kimura et $a l{ }^{1)}$ and Inoue $e t a l{ }^{2)}$ The oxygen contents are calculated from the measured oxygen activities in the present study using Eq. (7) on the assumption of $[$ mass ppm Ca] $=1$, which are also plotted in Fig. 7(a). The dashed curves in Fig. 7 represent the equilibrium ones for Eq. (1) described by Suito et al.'s group, ${ }^{1,2)}$ using the thermodynamic data ${ }^{8,14)}$ shown in Table 5. The calculations are conducted by taking into account the atomic interactions shown in Table 5 and the activity of $\mathrm{Al}_{2} \mathrm{O}_{3}$ in $\mathrm{CaO}-\mathrm{Al}_{2} \mathrm{O}_{3}$ slag. With increasing $\mathrm{Al}$ content up to about $1 \mathrm{mass} \%$, the discrepancy is found to become larger between the results of equilibrium experiments and the calculated results. On the other hand, the solid curves in Fig. 7 represent the relationships of $\mathrm{Al}$ and $\mathrm{O}$ contents derived in the present study. It is found that the solid curve is in good agreement with the present and previ- 
Table 5. The equilibrium constant for the reaction of $\mathrm{Al}_{2} \mathrm{O}_{3}(\mathrm{~s})=2 \underline{\mathrm{Al}}+3 \underline{\mathrm{O}}$ and the interaction parameters used by Suito et al.'s group.

\begin{tabular}{|c|c|c|c|c|}
\hline \multirow{2}{*}{$\begin{array}{c}\text { Equilibrium constant } \\
\qquad \log K_{(1)}^{14)}\end{array}$} & \multicolumn{4}{|c|}{ Interaction parameters $^{8)}$} \\
\hline & $i$ & $j$ & $e_{i}^{j}$ & $r_{i}^{j}$ \\
\hline \multirow{2}{*}{$20.2-62800 / T$} & $\mathrm{Al}$ & $\begin{array}{c}\mathrm{Al} \\
\mathrm{O}\end{array}$ & $\begin{array}{c}0.045 \\
-6.6\end{array}$ & $\begin{array}{c}-0.001 \\
-\end{array}$ \\
\hline & $\mathrm{O}$ & $\begin{array}{c}\mathrm{Al} \\
\mathrm{O}\end{array}$ & $\begin{array}{c}-3.9 \\
-0.20\end{array}$ & $\begin{array}{c}1.7 \\
-\end{array}$ \\
\hline
\end{tabular}
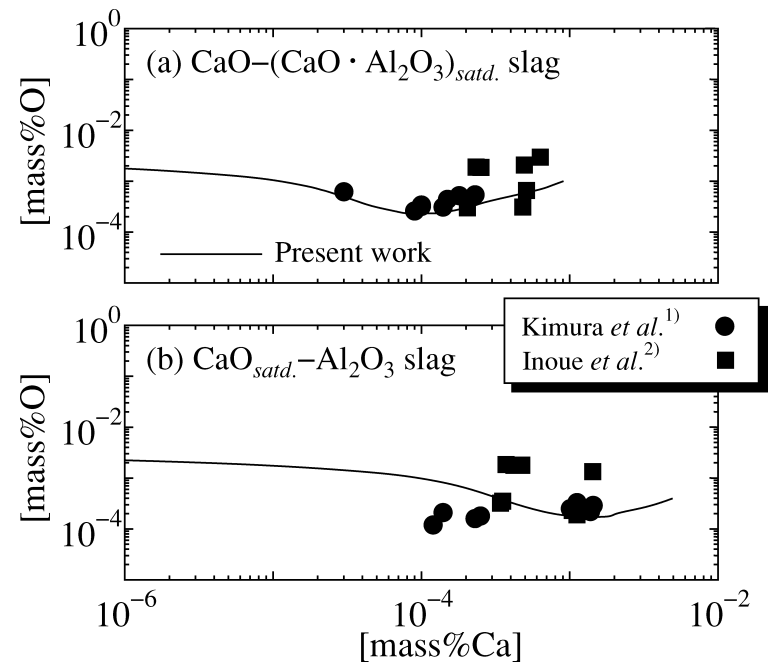

Fig. 8. Relationship between $\mathrm{Ca}$ and $\mathrm{O}$ contents of molten iron equilibrated with $\mathrm{CaO}-\left(\mathrm{CaO} \cdot \mathrm{Al}_{2} \mathrm{O}_{3}\right)_{\text {satd. }}$ or $\mathrm{CaO}_{\text {satd. }}$ $\mathrm{Al}_{2} \mathrm{O}_{3}$ slag at $1873 \mathrm{~K}$.

ous experimental results equilibrated with $\mathrm{CaO}-(\mathrm{CaO}$. $\left.\mathrm{Al}_{2} \mathrm{O}_{3}\right)_{\text {satd. }}$ slag at higher $\mathrm{Al}$ content from 0.1 to 1 mass $\% \mathrm{Al}$, in particular. In Fig. 7(b), the solid curve is not drawn over the range above 0.06 mass \% Al, because Eqs. (3) and (4) could not be solved simultaneously at the higher concentrations. The solid curve also reasonably agrees with the experimental results equilibrated with $\mathrm{CaO}_{\text {satd. }}-\mathrm{Al}_{2} \mathrm{O}_{3}$ slag in the described concentration range below about 0.06 mass $\%$ Al.

The relationships between $\mathrm{Ca}$ and $\mathrm{O}$ contents of molten iron are shown in Figs. 8(a) and 8(b) from the results equilibrated respectively with $\mathrm{CaO}-\left(\mathrm{CaO} \cdot \mathrm{Al}_{2} \mathrm{O}_{3}\right)_{\text {satd. }}$ and $\mathrm{CaO}_{\text {satd }}-\mathrm{Al}_{2} \mathrm{O}_{3}$ slags by Kimura et al. ${ }^{1)}$ and Inoue et al. ${ }^{2)}$ The solid curves in Fig. 8 show the relationships of $\mathrm{Ca}$ and $\mathrm{O}$ contents estimated in the present study under each deoxidation condition. In Fig. 8, the relationships of $\mathrm{Ca}$ and $\mathrm{O}$ contents are also in reasonable agreement with the solid curves estimated in the present study. In Fig. 7(b), the relationship of $\mathrm{Al}$ and $\mathrm{O}$ contents could not be described over the concentration range above $0.06 \mathrm{mass} \% \mathrm{Al}$; the validity of the experimental results equilibrated with $\mathrm{CaO}_{\text {satd. }}-\mathrm{Al}_{2} \mathrm{O}_{3}$ slag could not be evaluated at the higher $\mathrm{Al}$ concentrations.
With respect to the relationship of $\mathrm{Ca}$ and $\mathrm{O}$ contents described in Fig. 8(b), the experimental results reasonably agree with the relationship derived in the present study. From these examinations, it is found that the complex deoxidation equilibria of molten iron by aluminum and calcium derived in the present study are considered to be valid.

\section{Conclusions}

The oxygen activity in molten iron deoxidized by $\mathrm{Al}$ and $\mathrm{Ca}$ has been measured by an EMF method at $1873 \mathrm{~K}$, and the complex deoxidation equilibria of molten iron by aluminum and calcium have been examined. The conclusions are as follows:

(1) The complex deoxidation equilibria of molten iron by aluminum and calcium are described by applying the reliable thermodynamic data on the single deoxidation of molten iron by aluminum or calcium.

(2) The validity of the Al-Ca complex deoxidation equilibria presented in the present study is confirmed from the present and previous experimental results on the complex deoxidation by $\mathrm{Al}$ and $\mathrm{Ca}$, and the relationship of $\mathrm{Fe}-\underline{\mathrm{Al}}-\underline{\mathrm{Ca}}-\underline{\mathrm{O}}$ system can be represented more properly than previously reported ones.

\section{Acknowledgments}

The authors wish to thank Mr. K. Terauchi in Heraeus Electro-Nite Japan, LTD., for his kind help in making the oxygen sensor. Helpful discussion with Prof. I. Katayama of Osaka University is also gratefully acknowledged. This study was financially supported by JFE 21 st Century Foundation.

\section{REFERENCES}

1) T. Kimura and H. Suito: Metall. Mater. Trans. B, 25B (1994), 33.

2) R. Inoue and H. Suito: Steel Res., 65 (1994), 403.

3) H. Itoh, M. Hino and S. Ban-ya: Tetsu-to-Hagané, 83 (1997), 695.

4) H. Itoh, M. Hino and S. Ban-ya: Tetsu-to-Hagané, 83 (1997), 773.

5) C. H. Lupis: Chemical Thermodynamics of Materials, Elsevier Science Publishing Co., Inc., New York, (1983), 255.

6) The 19th Committee on Steelmaking, The Japan Society for the Promotion of Science : Steelmaking Data Sourcebook, Gordon and Breach Science Publishers, New York, (1988), 280, 282.

7) J. D. Seo, S. H. Kim and K. R. Lee: Steel Res., 69 (1998), 49.

8) G. K. Sigworth and J. F. Elliot: Met. Sci., 8 (1974), 298.

9) T. Fujisawa, M. Yamauchi and H. Sakao: CAMP-ISIJ, 1 (1988), 1115.

10) The 19th Committee on Steelmaking, The Japan Society for the Promotion of Science: Chemical Properties of Molten Slags, ed. by S. Ban-ya and M. Hino, ISIJ, Tokyo, (1991), 38.

11) B. Hallsteadt: J. Am. Ceram. Soc., 73 (1990), 15.

12) D. Janke: Arch. Eisenhüttenwes., 46 (1975), 477.

13) JANAF Thermochemical Tables, 3rd ed., ed. by M. W. Chase, Jr., C. A. Davies, J. R. Downey, Jr., D. J. Fruip, R. A. McDonald and A. N. Syverud: J. Phys. Chem. Ref. Data, 14 (1985), Supl. No. 2, 1601, 1608.

14) J. F. Elliott, M. Gleiser and V. Ramakrishna: Thermochemistry for Steelmaking, Vol. II, Addison-Wesley, Reading, MA, (1963), 547. 